\section{$\underset{\substack{\text { hommes } \\ \text { \& migrations }}}{ }$}

\section{Hommes \& migrations}

Revue française de référence sur les dynamiques

migratoires

1285 | 2010

L'appel du pied

\title{
Stephen Wright, La Polka des bâtards
}

Paris, Gallimard, 2010, 416 pages, 23 euros

\section{Mustapha Harzoune}

\section{Q OpenEdition}

1 Journals

\section{Édition électronique}

URL : http://journals.openedition.org/hommesmigrations/1224

DOI : 10.4000/hommesmigrations. 1224

ISSN : 2262-3353

\section{Éditeur}

Musée national de l'histoire de l'immigration

\section{Édition imprimée}

Date de publication : 1 mai 2010

Pagination : 206

ISSN : 1142-852X

\section{Référence électronique}

Mustapha Harzoune, «Stephen Wright, La Polka des bâtards », Hommes \& migrations [En ligne], 1285 |

2010, mis en ligne le 29 mai 2013, consulté le 22 septembre 2020. URL : http://

journals.openedition.org/hommesmigrations/1224; DOI : https://doi.org/10.4000/

hommesmigrations. 1224

Ce document a été généré automatiquement le 22 septembre 2020.

Tous droits réservés 


\title{
Stephen Wright, La Polka des bâtards
}

\author{
Paris, Gallimard, 2010, 416 pages, 23 euros
}

\section{Mustapha Harzoune}

\section{RÉFÉRENCE}

Stephen Wright, La Polka des bâtards, Paris, Gallimard, 2010, 416 pages, 23 euros

1 Liberty Fish ! Voilà qui s'appelle choisir le nom de son personnage. Libre et insaisissable à l'image de ces poissons qui filent et qu'on ne peut retenir. La Polka des bâtards raconte dans une langue protéiforme et majestueuse, inventive et truculente, les USA. Un pays et un peuple aussi insaisissables que n'importe quelle autre nation. Un pays et un peuple irréductibles à une formule et dont le devenir se nourrit des bâtardises et des contradictions des temps présents.

2 Ici Stephen Wright revient sur une question centrale de la société américaine, la question raciale. La Polka des bâtards a pour théâtre la guerre de Sécession. Liberty Fish est le rejeton d'un couple d'abolitionnistes convaincus et militants. Le père est newyorkais, quant à la mère, elle est issue d'une famille d'esclavagistes de la Caroline. L'État du Sud, comme la parentèle, figurent parmi les pires suppôts de la relégation du Noir à l'état de bête sauvage. De quoi donner des nausées à la jeune Roxana qui décide de quitter la plantation familiale, Rédemption Hall, et les siens.

3 Pas étonnant alors, quand éclate la guerre de Sécession, que Liberty Fish s'engage du côté Yankee et participe à ce qu'il croit être une guerre contre l'esclavagisme et pour l'égalité entre Blancs et Noirs. Le jeune homme sortira vivant du carnage. Ce sera-là son seul acte d'héroïsme, et pas des moindres à lire les descriptions dantesques des batailles et tueries.

4 Fatigué sans doute des boucheries dont il a été le témoin, revenu de ses illusions sur la nature humaine et sur ses camarades de combats, titillé aussi par ses troubles origines familiales, une fois de plus, Liberty s'esbigne, il déserte! Il part à pied, en direction de la proche Caroline, à la recherche de Rédemption Hall et de ses grands-parents. Histoire de comprendre et peut-être de faire payer le mal qu'ils ont fait à leur fille, sa mère. Ce 
qu'il va découvrir dépasse l'entendement, le grand-père expérimente ses théories raciales sur les esclaves encore en sa possession : pour se débarrasser de "la maladie de la différence raciale", "lever la malédiction de la couleur en éradiquant complètement toute couleur". Ce n'est pas un programme, mais un délire!

5 Stephen Wright met à mal bien des mythes qui participent de la gloriole nord américaine et joue du bistouri pour faire remonter à la surface les non-dits de l'histoire américaine, les héritages et les illusions de son histoire raciale. Il faut lire Stephen Wright pour ce qu'il raconte, d'une actualité étonnante, mais aussi et peut-être surtout pour son écriture torrentielle et vertigineuse. 